\title{
Demographic Trends and Dividends in the Russian Federation and the Kyrgyz Republic
}

Dinara S. Djoldosheva ${ }^{+}$

\section{Abstract}

The article is dedicated to the demographic trends and the demographic dividend in the Russian Federation and the Kyrgyz Republic for the years of 1950-2015. Based on the UN database, there has been a gradual decrease in the total birth rate during 65 years in the Russian Federation and the Kyrgyz Republic. However, in the Kyrgyz Republic, this number was almost twice its level in the Russian Federation. The overall demographic burden was significantly lower in the Russian Federation from 1960 to 2005, and its decrease in both countries was due to the decrease in the demographic burden of children. Since 1960, and during the following decades, the demographic burden of elderly people in the Russian Federation began to increase rapidly, but in the Kyrgyz Republic, the decrease in demography was due to changes in the age structure of the population. In the result of these trends, the share of the working-age population in both countries has steadily increased, creating favourable conditions for the demographic dividend. Russia and Kyrgyzstan, due to the high share of the working-age population over the past 55 years, have received a demographic dividend. Labour migration from Kyrgyzstan to Russia makes a significant contribution to the demographic dividend of both countries.

Keywords: Total Birth Rate, Demographic Burden, Demographic Transition, Demographic Dividend, Depopulation

\footnotetext{
' Department of Economic Theory, Kyrgyz-Russian Slavic University named after B.N. Yeltsin, Bishkek, Kyrgyz Republic, 720022, Email: ddjoldosheva@yahoo.com

(C) 2019 Djoldosheva. This is an Open Access article distributed under the terms of the Creative Commons Attribution License (http://creativecommons.org/licenses/by/2.0), which permits unrestricted use, distribution, and reproduction in any medium, provided the original work is properly cited.
} 


\section{Introduction}

A significant number of scientific studies are dedicated to the demographic transition that occurs in the result of changes in birth, mortality, fertility (total birth rate), migration, ethnic composition and marital behaviour of the population, etc. (Landry, 1934; Davis, 1945; Notestein, 1945; Demeny, 1968; Van de Kaa, 1987; Lee \& Mason, 2010; Gribble \& Bremner, 2012; Vishnevskiy, 1982; Vishnevskiy, 2014; lontsev, 2007; lontsev \& Prokhorova, 2014; Ivanov, 2017; Akhmetshin et al., 2018). Earlier, in 1998, in their research on extensive comparative studies on changes in the age structure of the population as a result of reduced birth, mortality and fertility that led to the increase of number of working-age population regarding dependents (children and elderly people), Bloom D. and Williamson J., used the concept of "demographic gift"1 (Silagadze, 2017; Silagadze, 2018).

In the further studies of Bloom D. and other researchers, including from Russia, the definition of "demographic dividend" 2 began to be used in a comprehensive way (Bloom \& Williamson, 1998; Bloom et al., 2003; Gribble, 2012; Gribble \& Bremner, 2012; Mason \& Tomoko, 2008; Luoma, 2016; Vasin, 2008; Abramova, 2014; Reyer, 2017). O'Sullivan J. \& Martin R. (O'sullivan and Martin, 2016) note that the demographic dividend is correlated to the temporary window of opportunity in which the share of the workingage population is unusually high regarding dependents. According to Gribble (2012), the most significant demographic dividend was obtained by the Asian Tigers (Indonesia, Malaysia, Singapore, Thailand and South Korea). For example, in South Korea, the accelerated demographic transition from high to low fertility led to the decrease of the demographic burden, thereby increasing of the share of the working- age population regarding dependants and conditioned an annual GDP growth per capita by $6.7 \%$ in the years of $1960-1990$. This success was accomplished due to well-cooperated social and economic policies, investment in healthcare and education, infrastructure and production (Luoma, 2016; Dovidauskas et al., 2018).

International migration has become a leading factor in the demographic trends in the modern world (lontsev, 2007). According to Klum (2016), migration, along with urbanisation, changes of life expectancy and birth, led to significant social, political, economic and environmental transformations (Egeberg \& Stigen, 2018). The above-stated processes are proper to most countries of the world, so studying demographic trends and the demographic dividend in the Russian Federation (the RF) and the Kyrgyz Republic (the KR) is an important aspect. Based on this rationale, this research aims to explore the following objectives:

- to compare the dynamics of the total fertility rate in the Kyrgyz Republic and the Russian Federation;

- to analyse the difference of the demographic burden in these two countries;

- to study the changes in the age structure of the population;

- to study the issues of labour migration;

- to determine the ratio of demographic burden;

- to conclude the working capacity of the population.

The research begins with a brief description of the materials and methods entailed. This follows a critical discussion of the results.

\section{Materials and Methods}

With the aim of comparative studying the demographic trends and the demographic

\footnotetext{
${ }^{1}$ Demographic gift is an indicator that depends on the age structure of the population, which is characterised by a decrease in fertility, mortality and fertility, which caused an increase in the number of able-bodied part of the population in relation to dependents (children and the elderly).

2 Demographical dividend is the indicator related to potential benefits which can increase the share of working population in total population and decrease the share of population dependent on others after the process of demographic transition is complete.
} 
dividend in the Russian Federation and the Kyrgyz Republic, a single UN database on fertility dynamics (total birth rate) for the years of 19502015 (UN World Population Prospects. The 2010 Revision. Prospects after 2010) had been employed. The critical analysis is based on the comparative method through which one can see the dynamics of changes of the demographic burden in the Kyrgyz Republic and the Russian Federation.

The findings (discussed below) revealed that the demographic dividend represents an opportunity to ensure rapid income growth and poverty reduction (Gribble \& Bremner, 2012). International migration has become a leading factor in the demographic trends in the modern world (lontsev, 2007). According to D. Klum (2016), migration along with urbanisation, changes of life expectancy and fertility led to significant social, political, economic and environmental transformations. It is arguable that these indicators and processes apply to most countries of the world (cite references from different parts of the world). Hence, studying demographic trends and the demographic dividend in the Russian Federation (the RF) and the Kyrgyz Republic (the KR) remains imperative. The results of the research are discussed in the following sections.

\section{Results}

A comparative analysis of the dynamics of the total birth rate (the TBR) in the KR and the RF for the years of 1950-2015, according to the UN World Population Prospects (United Nations, 2011), is shown in Figure 1. As can be seen from this figure, during 65 years the TBR in the KR was almost twice its level in Russia. The maximum level of the TBR, respectively, 5.39 children per woman in 1960-1965 in the KR decreased to 2.62 in 2010-2015.

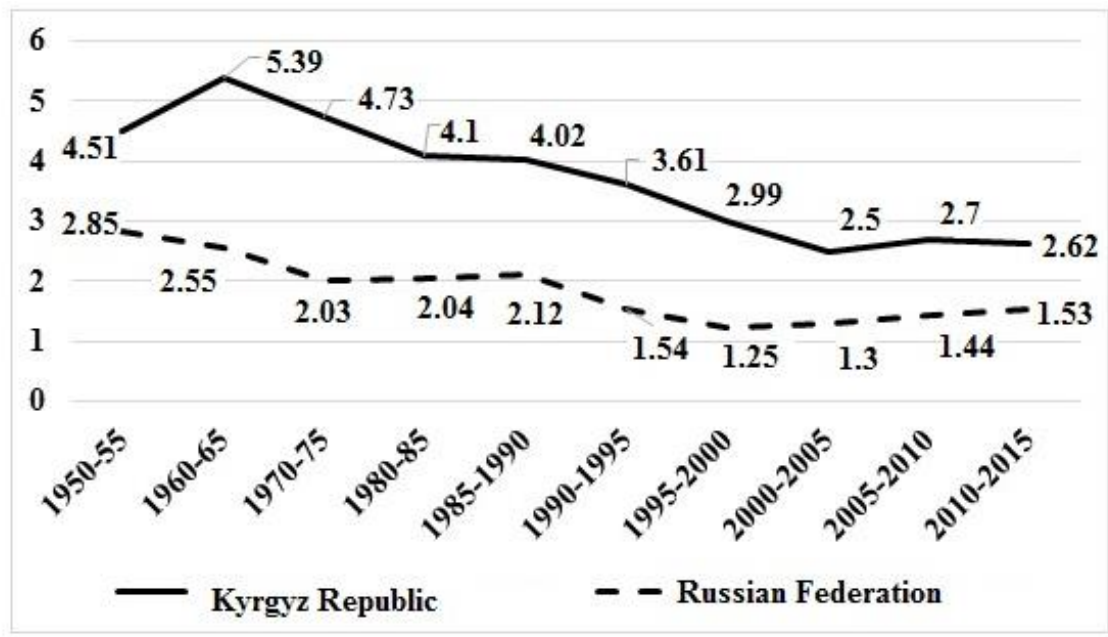

Figure 1: Dynamics of the total birth rate in the Kyrgyz Republic and the Russian Federation (1950-2015) (UN World Population Prospects. The 2010 Revision. Prospects after 2010)

In the RF, the highest value of this indicator was 2.85 children per woman was observed in the years of 1950-1955, and the lowest was 1.25 - in the years of 1995-2000. These differences in the TBR affected the overall demographic burden in the $K R$ and the RF. As shown in Figure 2, the overall demographic burden in the $K R$ was significantly higher than in the RF from 1960 to 2005.
However, in 1950, the difference between this indicator in the Russian Federation and the Kyrgyz Republic was not so significant (respectively, 580 and 541 per 1000 population). The highest level of the total demographic burden in the KR was observed in 1970 (919 per 1000 population) exceeding its value in the RF by 1.8 times (521 per 1000 population). By 2010, this figure had decreased in both countries, having reached in the RF and the KR 386 and 526 per 1000 population. As can be seen from Figure 
3 , the decrease in the overall demographic 1950, the demographic burden of children in the burden was mainly due to the demographic KR and the RF was approximately the same (459 burden of children. It should be noted that in and 445 per 1000 population).

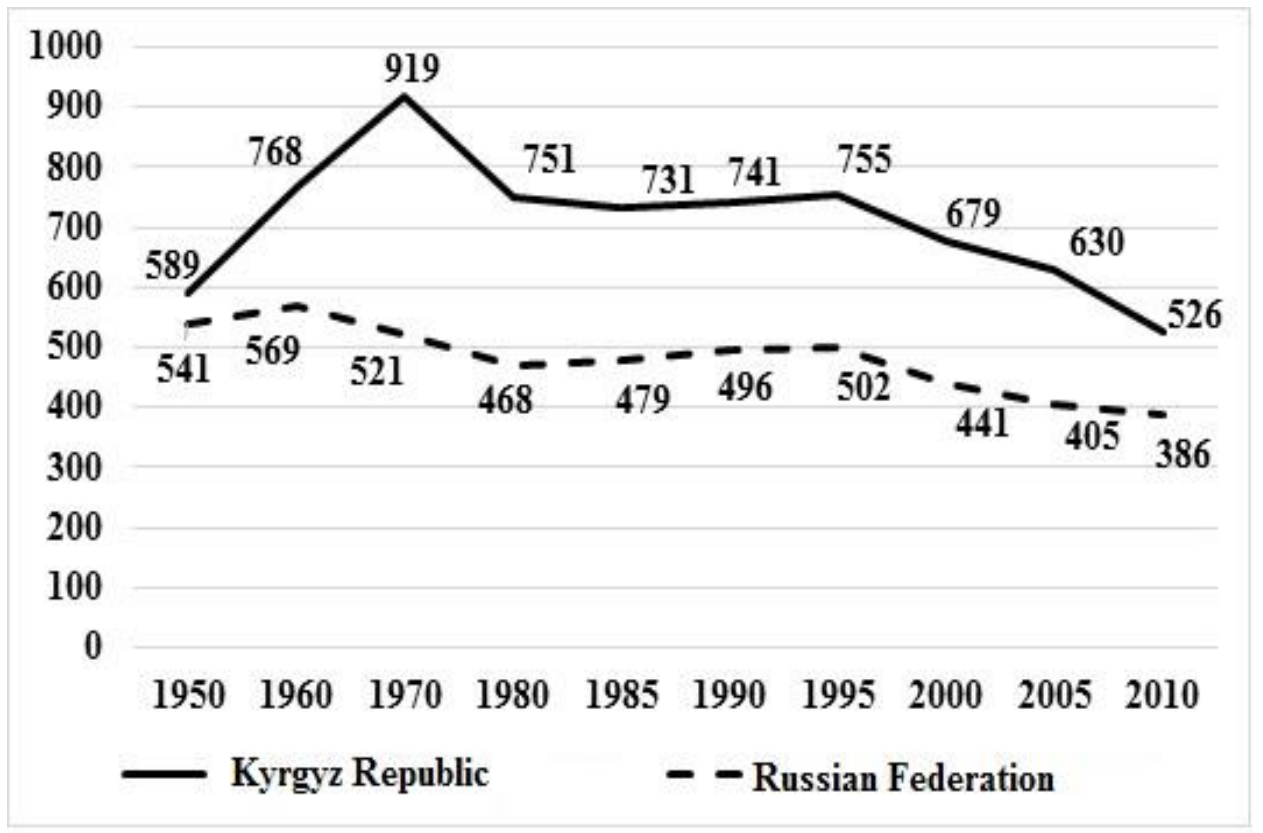

Figure 2: Comparative analysis of the total demographic burden in the Kyrgyz Republic and the Russian Federation (1950-2015) (UN World Population Prospects. The 2010 Revision. Prospects after 2010)

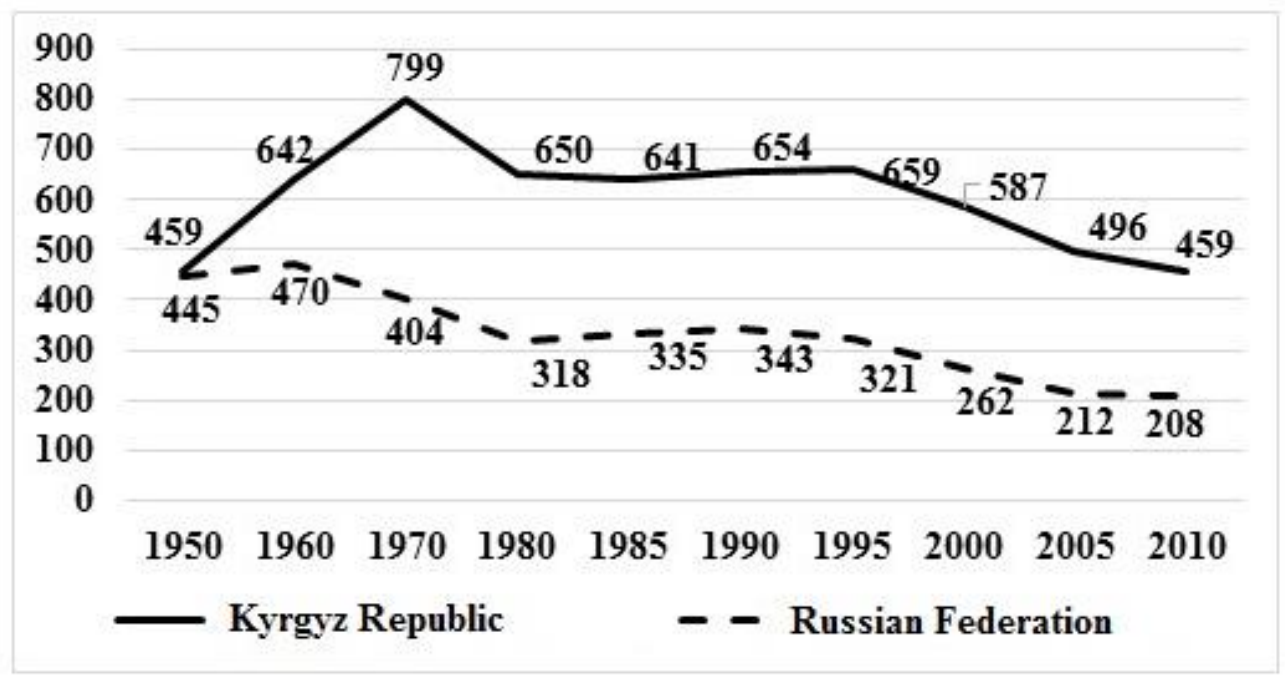

Figure 3: Dynamics of the demographic burden of children in the Kyrgyz Republic and the Russian Federation (1950-2010) (UN World Population Prospects. The 2010 Revision. Prospects after 2010)

However, in 1970, this figure in the KR exceeded its level in the RF almost two times (respectively, 799 and 404 per 1000 population). In the following decades, both countries saw a gradual decline in the demographic burden of children, but the difference remained more or less than twofold until 2010. In contrast to the unidirectional dynamics of the demographic burden of children in the KR and the RF, the demographic burden of elderly people was multidirectional (Figure 4). Thus, in the KR this figure in 1950 and 1960 was higher (respectively, 129 and 125 per 1000 population) than in the RF (respectively, 95 and 99 per 1000 population). In 
the following decades, the demographic burden of elderly people in the Russian Federation began to increase rapidly and reached 193 and 177 per 1000 population in 2005 and 2010, and in the KR it began to fall to 89 and 68 per 1000 population. These trends were due to changes in the age structure of the population of the RF and the KR that occurred in the years of 1950-2010 (Figures 5 and 6).
As shown in Figure 5, the share of children in the RF almost halved from $28.9 \%$ in 1950 to $15.0 \%$ in 2010 , and the share of elderly people increased from $6.2 \%$ to $12.8 \%$. As a result, the share of the working-age population of the RF significantly increased from $64.9 \%$ in 1950 to $72.2 \%$ in 2010.

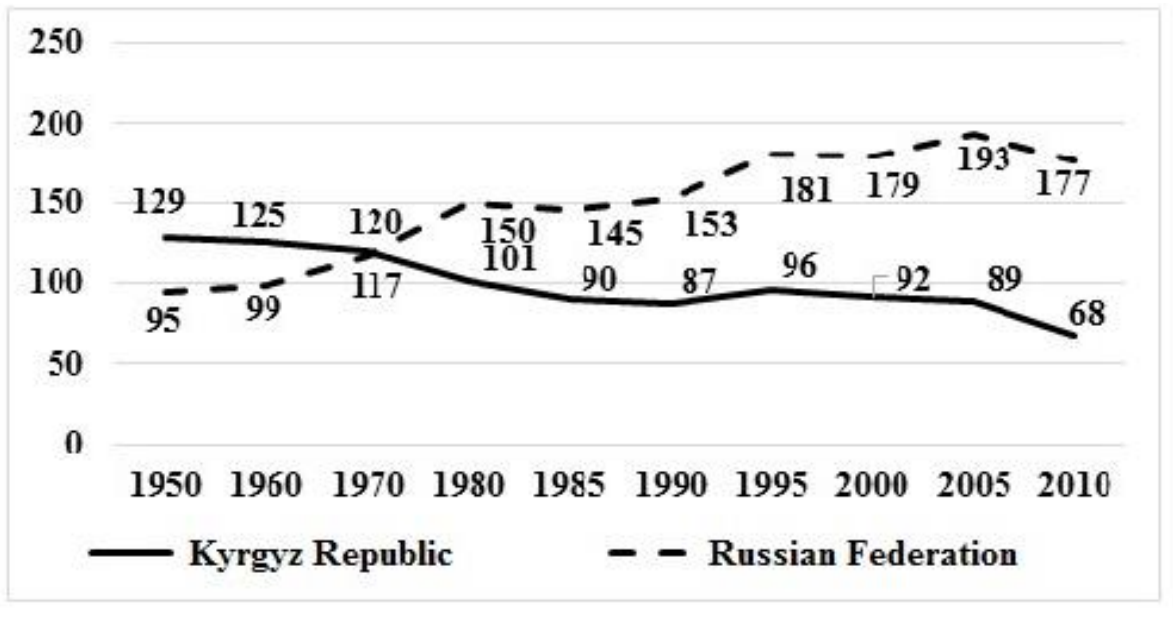

Figure 4: Dynamics of the demographic burden of elderly people in the Kyrgyz Republic and the Russian Federation (1950-2010) (UN World Population Prospects. The 2010 Revision. Prospects after 2010)

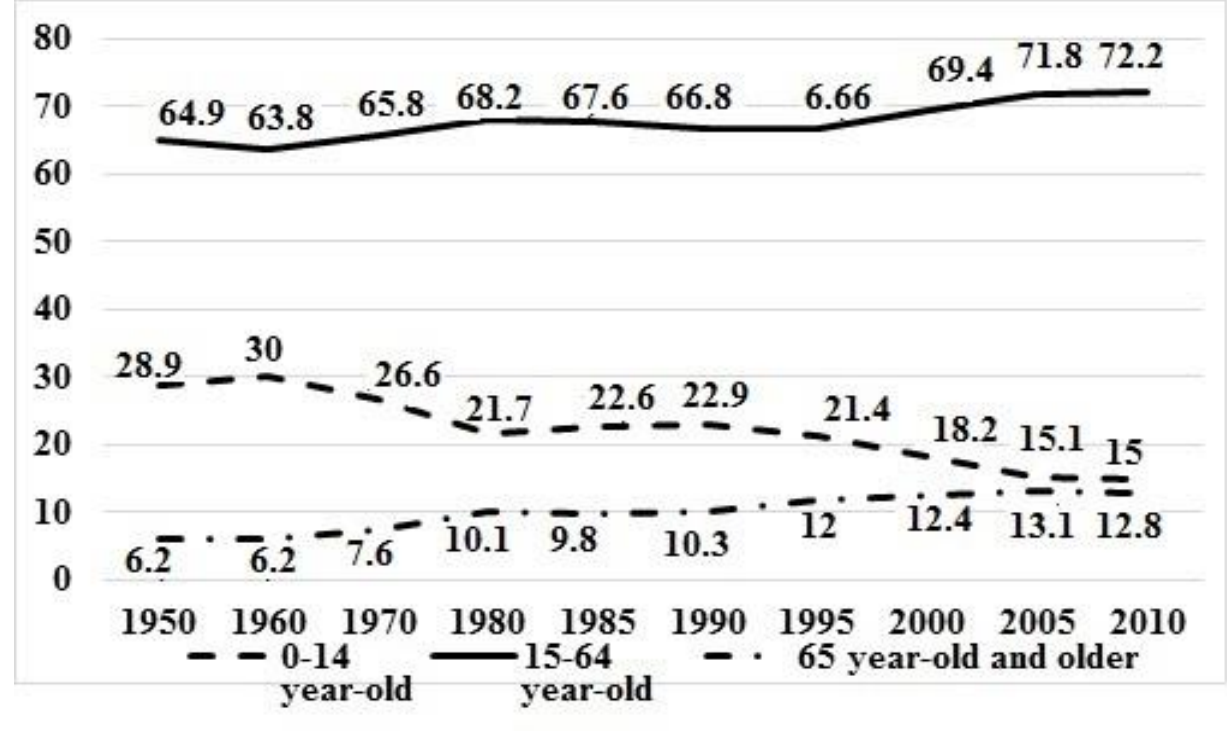

Figure 5: Changes of the age structure of the population of the Russian Federation (1950-2010) (UN World Population Prospects. The 2010 Revision. Prospects after 2010) 


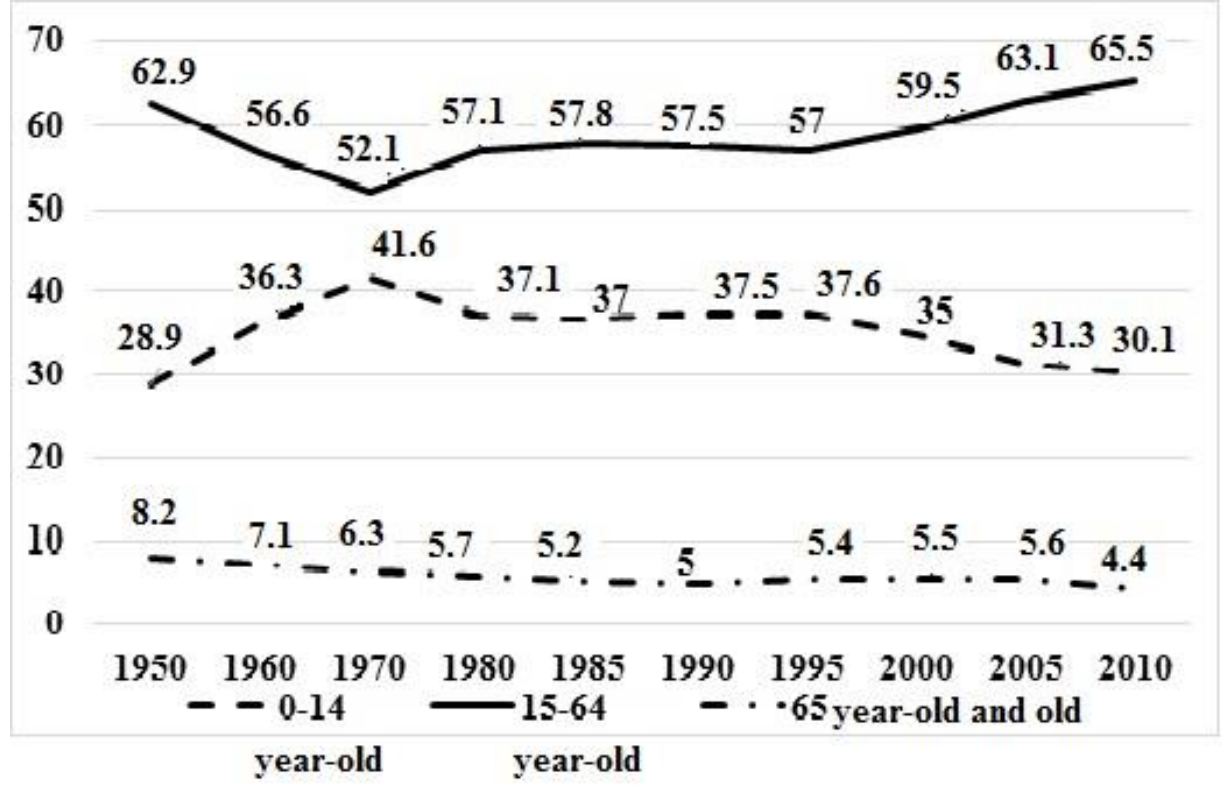

Figure 6: Changes of the age structure of the population of the Kyrgyz Republic (1950-2010) (UN World Population Prospects. The 2010 Revision. Prospects after 2010)

In the KR, the share of children increased from $28.9 \%$ in 1950 to $41.6 \%$ in 1970 and then gradually decreased to $30.1 \%$ in 2010 . The share of elderly people almost halved from $8.2 \%$ in
1950 to $4.4 \%$ in 2010 . In the result of these trends, the share of the working-age population has reached a historic low of $52.1 \%$ in 1970 , rose to $65.5 \%$ in 2010 .

\begin{tabular}{|c|c|c|c|c|c|c|c|c|c|}
\hline Country & 1950 & 1960 & 1970 & 1980 & 1990 & 1995 & 2000 & 2005 & 2010 \\
\hline Russia & 1.84 & 1.76 & 1.92 & 2.15 & 2.01 & 1.99 & 2.26 & 2.54 & 2.59 \\
\hline Kyrgyzstan & 1.69 & 1.30 & 1.08 & 1.33 & 1.35 & 1.32 & 1.46 & 1.71 & 1.89 \\
\hline
\end{tabular}

\section{Discussion}

The above trends affected the demographic burden coefficient (the correlation of the working-age population to dependants). As can be seen from Table 1, this figure was significantly higher in the RF compared to the KR, especially, from 1960 to 2010. In 1960, the demographic burden coefficient in Russia was 1.76, and in Kyrgyzstan, it stood at 1.3. In 2010, this (see, Figure 6) increased in the RF to 2.59 and 1.89 in the KR. Due to the high demographic burden coefficient, Russia has received a significant demographic dividend over the past 50 years (Vasin, 2008; Egeberg \& Stigen, 2018; Akhmetshin et al., 2018). However, during the transition period, the positive effect of the demographic dividend in Russia had been blurred by profound economic and political destabilisation.

Nevertheless, demographic tendencies made a significant contribution to economic growth at the end of the transition period. According to the World Bank (2015), in 1997-2011 in Russia, the demographic dividend, due to the high share of the working-age population, provided a third of the GDP growth per capita at the average annual rate of $4.9 \%$. The increase of one percentage point in the share of the working-age population in Russia, excluding migration, means an 
increase of GDP per capita by 1.6\% (World Bank, 2015).

However, a decade ago, Vasin(2008: 15) predicted that Russia would face a complete the stage of "depopulation with a demographic dividend" in which an increase in the workingage population will follow a decline of the total population. A report published by the World Bank (2015) reinforced the prediction of Vasin (2008) - there has been a decline in the share of the working-age population, and growth of the share of the elderly population and, consequently, the demographic burden in Russia is gradually heading towards causing severe socio-economic problems. Therefore, the decree of the Russian President on the Concept of the State Migration Policy of the Russian Federation for 2019-2025 (dated 31 October 2018 and the Federal Law On Making Amendments to Certain Legislative Acts of the Russian Federation on the Appointment and Payment of Pensions No. 350 - FA, approved on 03 October 2018 are timely, which will perhaps, make an undoubted positive contribution to the solution of these problems.

According to Riazantsev (2016), labour migration from Central Asia to Russia is between 2.7-4.2 million or $10-16 \%$ of the economically active population of the region. In 2013, the scope of remittances from labour migrants amounted to the US $\$ 13.5$ billion. At the same time, the income of the Russian economy amounted to the US \$1.6 billion only due to the current consumption of labour migrants. In the external migration processes, mainly in the RF, workingage share of the population of the $K R$ participates most actively.

In 2011-2014, it was about $79-87 \%$ of the total number of the Kyrgyz migrants. The share of young people, aged between 18-29 amongst the total number of migrants was $47 \%$. In different years, from $12.5 \%$ to $19.5 \%$ of labour migrants from Kyrgyzstan had higher education; $16.8 \%$ to $23.4 \%$-had secondary special education and from $28.2 \%$ to $52.3 \%$ had secondary general education (Single Report on Migration about the Kyrgyz Republic, 2014). This shows that an educated and working-age share of the population, which makes a specific contribution to the economy of the host country emigrates from Kyrgyzstan to Russia (lontsev V., 2007). On the other hand, the scope of cash transfers from the Kyrgyz labour migrants for 2007-2017 reached $27-34 \%$ of the KR GDP (Kyrgyzstan report: National Study on Child Mortality and Inequalities, 2009; World Bank, 2017). Thus, labour migration from Kyrgyzstan to Russia has a double positive value, on the one hand, it enlarges the share of the working-age population of the Russian Federation and, on the other hand, brings a demographic dividend for the KR.

It should be noted that, despite the low level of the demographic burden coefficient in the KR during the past 50 years (1960-2010), there was economic growth in the KR. This is due to governmental grants from Moscow during the USSR period. Thus, the economy of the KR in the second half of the 1960s and the first half of the 1980s formed a diversified industry, which produced $80 \%$ of the total social product and accounted for more than half of the national income of the Republic (Dzhunushaliyev, 1994). In this period, by the rates of growth of national production income, the KR was ahead of several Republics- Ukraine, Kazakhstan, Lithuania, Moldova, Turkmenistan and Estonia.

For 20 years (that is, from 1965-1985) the national income increased by 2.7 times, while the scope of industrial production increased by 4.4 times, the scope of engineering and metal processing products increased by almost eight times. In 1985, the production of electric power increased by 12 times compared to 1960 . More than 150 industrial enterprises were established in the Republic in a relatively short time. The economic growth in the Kyrgyz Republic after the Second World War is also evidenced by the data of the (Nur, 2016). It should be noted that, according to the OECD (Bolt et al., 2014), the GDP per capita in the former USSR increased from \$ 3945 to \$ 6894 in the PPP (purchasing power parity) from 1960 to 1990, respectively, and this was a significant share of Russia's demographic dividend. After the USSR collapsed in 1991, the economic situation in the post- 
Soviet republics, including the $K R$, changed radically.

\section{Conclusion}

The purpose of the current research was to determine the demographic trends and dividends in the RF and the KR. A gradual decrease in the total birth rate during 65 years (1950-2015) was observed in the RF and the KR while this figure in the KR was almost twice its level in the RF. The differences in the total birth rate affected the overall demographic burden, which was significantly lower in Russia from 1960 to 2005. The decrease in the overall demographic burden in both countries was mainly due to the drop in the demographic burden of children. In contrast to the unidirectional dynamics of the demographic burden of children in the KR and the RF, the demographic burden of elderly people was multidirectional.

Since 1960, and during the following decades, the demographic burden of the elderly people has begun to increase in the RF rapidly, but declining in the KR. These trends were due to changes in the age structure of the population of the RF and the KR that occurred in 1950-2010. In Russia, the share of children reduced by almost two times while the share of the elderly people also increased by two times. In the $K R$, by contrast, the share of elderly people almost halved. Over the past two decades, labour migration from Kyrgyzstan to Russia made a significant contribution to the demographic dividend of both countries. As a result of these trends, the share of the working-age population in both countries steadily increased, creating favourable conditions for the demographic dividend. Russia and Kyrgyzstan, due to a high share of the working-age population for 55 years, received a significant demographic dividend.

\section{References}

Abramova, I. (2014). Demographic dividend and the future development of the mankind. Retrieved on 05 April 2019 from, https://ru.exrus.eu/Demograficheskydividend-i-budushcheye-razvitiye- chelovechestva-

id53ae8f70ae20153b7d347e7f

Akhmetshin, E.M., Sharafutdinov, R.I., Gerasimov, V.O., Dmitrieva, I.S., Puryaev, A.S., Ivanov, E.A., Miheeva, \& N.M. (2018). Research of human capital and its potential management on the example of regions of the Russian Federation. Journal of Entrepreneurship Education, 21(2), 15282651-21-2-172.

Bloom, D., \& Williamson, J. (1998).

Demographic trends and economic miracles in emerging Asia. World Bank Economic Review, 12(3), 419-455.

Bloom, D., Canning, D., \& Sevilla, J. (2003). The demographic dividend: a new perspective on the economic consequences of population change. In Population Matters Monographs MR-1274 (pp. 18-23). Santa Monica: RAND.

Bolt, J., Timmer, M., \& Van Zanden, J. (2014). GDP per capita since 1820 . How Was Life? In Global Well-being since 1820 (pp. 57-72). Paris: OECD Publishing.

Davis, K. (1945). The world demographic transition. Annals of the American Academy of Political and Social Sciences, 237, 1-11.

Demeny, P. (1968). Early fertility decline in Austria-Hungary: a lesson in demographic transition. Daedalus, 97, 502-522.

Dovidauskas, S., Okada, I.A., Iha, M.H., Cavallini, A.G., De Oliveira, M.A. (2018). Approach on detection of situation of potential risk to health, related to water quality: an example. Periodico Tche Quimica, 15(29), 123-135.

Dzhunushaliyev, D.D. (1994). Kyrgyzstan in the years of reforms from above (1950-1991). Bishkek: Kyrgyz Russian Slavic University named after the First President of Russia B.N. Yeltsin.

Egeberg, M., \& Stigen, I.M. (2018). Explaining government bureaucrats' behaviour: On the relative importance of organizational position, demographic background, and political attitudes. Public Policy and Administration. Retrieved from 
https://journals.sagepub.com/doi/full/10.11 77/0952076718814901

Gribble, J. (2012). South Korea's demographic dividend. Population Reference Bureau. Retrieved on 05 April 2019 from, https://www.prb.org/south-koreapopulation/

Gribble, J., \& Bremner, J. (2012). Achieving a demographic dividend. Population Bulletin, 27(2), 154-167.

lontsev, V.A. (2007). Population economics. Moscow: INFRA-M.

Iontsev, V.A., \& Prokhorova, Yu.A. (2014). International migration in the context of demographic theory. Standard of Living of the Population of the Russian Regions, 193(3), 83-91.

Ivanov, S. (2017). Determinants of demographic transition in the global South. Demographic Review, 4(2), 6-52.

Klum, D. (2016). Demographic shocks. Finance and Development, 53(1), 6-11.

Kyrgyzstan report: National Study on Child Mortality and Inequalities. (2009). Bishkek: UNICEF. Retrieved from https://www.unicef.org/socialpolicy/files/Ky rgastan_RussianChildPovertyReport.pdf

Landry, A. (1934). La revolution demographique. Paris: INED.

Lee, R., \& Mason, A. (2010). Fertility, human capital, and economic growth over the demographic transition. European Journal of Population, 26(2), 159-182.

Luoma, K. (2016). South Korea's demographic dividend: a success story. Population Education. Retrieved on 10 April 2019 from, https://populationeducation.org/southkoreas-demographic-dividend-success-story/

Mason, A., \& Tomoko, K. (2008). East Asian economic development: two demographic dividends. Journal of Asian Economics, 19, 389-399.
Notestein, F. (1945). Population - the long view. In T.W. Schultz (Ed.). Food for the World (pp. 37-57). Chicago: University of Chicago Press.

Nur, U.D. (2016). Post-war restructuring of the Kyrgyz economy. Journal of Kyrgyz Russian Slavic University named after the First President of Russia B.N. Yeltsin, 16(12), 5861.

O'Sullivan, J., \& Martin, R. (2016). The risk of misrepresenting the demographic dividend. $N$-IUSS. Retrieved on 11 April 2019 from, http://www.niussp.org/article/the-risk-ofmisrepresenting-the-demographicdividendle-risque-dune-interpretationerronee-du-dividende-demographique/

Reyer, D. (2017). Economic and social consequences of the demographic transition. Demographic Review, 1(4), 41-67.

Riazantsev, S. (2016). Economic and social consequences of the demographic transition. Demographic review. Retrieved on 06 April 2019 from, https://globalaffairs.ru/valday/Trudovayamigratciya-iz-Tcentralnoi-Azii-v-Rossiyu-vkontekste-ekonomicheskogo-krizisa-18333

Silagadze, A. (2017). History of Georgian economic thought: Relation between the center and the region. Bulletin of the Georgian National Academy of Sciences, 11(4), 138-144.

Silagadze, A. (2018). Some aspects of economic ideas in Shota Rustaveli's "the knight in the panther skin". Bulletin of the Georgian National Academy of Sciences, 12(1), 161167.

Single Report on Migration about the Kyrgyz Republic. (2014). Retrieved on 07 April 2019 from, https://www.auca.kg/uploads/Tian\%20Shan \%20Policy\%20Center/TSPC\%20Publications/ Unified\%20Migr\%20Report_2014.pdf

United Nations. (2011). World population prospects: the 2010 revision. Prospects after 2010. Retrieved on 15 April 2019 from, http://www.un.org/en/development/desa/p opulation/publications/pdf/trends/WPP2010 
/WPP2010_Volume-I_ComprehensiveTables.pdf

Van de Kaa, D. (1987). Europe's Second Demographic Transition. Population Bulletin, 42(1), 1-59.

Vasin, S. (2008). From depopulation with a dividend to the depopulation with no dividend. Demoscope Weekly. Retrieved on 14 April 2019 from, http://www.demoscope.ru/weekly/2008/03 17/tema02.php
Vishnevskiy, A.G. (1982). Reproduction of the population and society: history, modernity, view to the future. Moscow: Finansy $i$ Statistika.

Vishnevskiy, A.G. (2014). Demographic revolution changes the reproductive strategy of Homo Sapiens species. Demographic Review, 1(1), 6-33.

World Bank. (2015). In search of a new "silver age" in Russia: factors and consequences of population ageing. Moscow: Alex Publishers. 